\title{
Expression and Polymorphism Analysis of CFL2 Gene in Chinese Dabieshan Cattle
}

\author{
Shuanping Zhao, Lei Xu, Hai Jin and Yutang Jia* \\ Institute of Animal Husbandry and Veterinary Medicine, Anhui Academy of Agricultural \\ Sciences, Anhui Province Key Laboratory of Livestock and Poultry Product Safety \\ Engineering, Hefei, 230031, China.
}

\begin{abstract}
A B S T R A C T
Cofilin 2 (CFL2) is essential for skeletal muscle development and maintenance through regulating the length of actin filaments. In this study, we aimed to identify common variations in CFL2 gene and investigate their effects on growth traits in Chinese Dabieshan (DBS) cattle. By DNA sequencing and (forced) PCR-RFLP methods, three polymorphisms (g.1500G $>$ A, g.1694T $>$ A and g.2213C $>$ G) were identified and genotyped in our population $(\mathrm{n}=298)$. Genetic diversity analysis showed that $\mathrm{g} .1500 \mathrm{G}>\mathrm{A}$ and g.1694T $>$ A belonged to an intermediate level of genetic diversity $(0.25<\mathrm{PIC}<0.5)$, and SNP g.2213C $>\mathrm{G}$ belonged to a low polymorphism level ( $\mathrm{PIC}<0.25)$. LD (Linkage disequilibrium) analysis showed that SNP g.1694T $>$ A and g.2213C $>$ G had a strong linkage $\left(r^{2}>0.33\right)$, a total of four different haplotypes were constructed and the frequency of the main haplotypes AAG accounted for over $61.2 \%$ of the total individuals. Association analysis indicated that all of the three SNPs were significantly associated with growth traits in the detected population. Furthermore, real-time PCR indicated that CFL2 mRNA was varied expressed in all studied tissues. The results of our study provide evidence that polymorphisms in CFL2 gene are associated with growth traits, and CFL2 gene could be utilized as molecular markers for future assisted selection in cattle breeding program.
\end{abstract}

\begin{tabular}{l} 
Article Information \\
\hline Received 25 June 2018 \\
Revised 02 April 2019 \\
Accepted 10 June 2019 \\
Available online 18 March 2021 \\
Authors' Contribution \\
\hline YJ conceived and designed the entire \\
experimental plan. SZ performed the \\
experiment, did the statistical analysis \\
and drafted the manuscript. LX and \\
HJ participated in sample collection \\
and growth trait measurements. \\
Key words \\
\hline CFL2 gene, Dabieshan (DBS) cattle, \\
Polymorphism detection, Expression, \\
Association analysis
\end{tabular}

\section{INTRODUCTION}

$\mathrm{D}$ abieshan cattle are a precious local breed belonging to the central plains group and found in Anhui Province. They are usually red in hair, small in physique, strong in bones, well proportioned in development, and have the superiority such as crude feed tolerance, higher disease resistance and adaptation to environment.

Cofilins are part of the minimum set of proteins that are essential in embryonic development, health and disease. While it was first discovered in porcine brain (Nishida et al., 1984), many cofilin homologues have been characterized genetically and biochemically in various organisms including vertebrate, plant and protozoan system (Abe et al., 1990; McKim et al., 1994; Ono et al., 1994). With the role in remodelling the actin cytoskeleton, CFL1 is enriched in sub-cellular locations that are associated with high actin turnover, specifically in neuronal axons and the contractile rings formed during the final stages of mitosis (Bamburg, 1999; Maciver et al., 2002; Vartiainen et al., 2002). CFL2, by contrast, is predominantly localized

\footnotetext{
Corresponding author: yutang2018@163.com 0030-9923/2021/0003-0843\$9.00/0

Copyright 2021 Zoological Society of Pakistan
}

between the Z-discs in muscle sarcomeres, where it regulates the length of actin filaments (Kremneva et al., 2014).

Three isoforms: actin depolymerizing factor (ADF, also known as destrin), cofilin-1 (CFL1) and cofilin-2 (CFL2), were expressed in human and mice (Maciver et al., 2002). Further study indicated that CFL1 was predominantly expressed in embryonic mouse striated muscle, while during subsequent muscle development, CFL2 expression increases to become the predominant isoforms (Mohri et al., 2000). In human, the mutations of CFL2 gene causing nemaline myopathy, indicating that it play a critical role in skeletal muscle function, including development and maintenance (Agrawal et al., 2007; Ong et al., 2014). Another study indicated that CFL2 gene, although not critical for muscle development, is essential for muscle maintenance (Gurniak et al., 2014).

As the research moves along, more potential characteristics of CFL2 gene were discovered. Recent research found that CFL2 gene may be a key candidate in growth traits of domesticated animal. In chicken, g. $2545 \mathrm{G}>$ A polymorphism was significantly associated with shank girth and shank length at 4 weeks $(\mathrm{P}<0.05)$ (Zhao, 2011). In Chinese QC (Qinchuan) cattle, three SNPs of CFL2 gene were significantly associated with growth 
traits, including rump length, chest girth, chest breadth, chest depth, hip width and body mass $(\mathrm{P}<0.01)$ (Sun et al., 2015). The studies indicated that $C F L 2$ gene may involve in animal growth traits through exerting its effect on actin. However, more studies should be carried out to validate the function of CFL2 gene in animal growth and development.

Current studies indicated that CFL2 gene is an attractive candidate gene for pathology, such as myopathies (Fattori et al., 2018), cardiomyopathy (Rangrez et al., 2017) and Gastric Cancer (Bian et al., 2018); however, little is known in animal growing development. To explore the functional implication of $C F L 2$ gene in Chinese DBS cattle, multiple approaches were undertaken in our study. The structure of bovine CFL2 gene was characterized and three SNPs were genotyped in studied cattle. Sequently, genetic diversity was analyzed and statistical analysis were undertaken to discover the relationship between the genetic variation and the growth traits of cattle. Finally, quantitative real-time PCR was employed to analyze the spatial expression of CFL2 mRNA in different tissues.

\section{MATERIALS AND METHODS}

\section{Sample collection and growth trait measurements}

This study was conducted on a total of 298 healthy and unrelated female DBS cattle (36 \pm 6 months old), and all these animals were reared in the County of Yingshang and Taihu, Anhui province. Both maintenance and feeding for all animals were similar according to the obligatory standards. Ear marginal tissues were collected from the aforementioned cattle, and genomic DNA were extracted using the TIANamp Genomic DNA Kit (TIANGEN, Beijing, China) and estimated by spectrophotometer, and then, the genomic DNA was diluted to $50 \mathrm{ng} / \mu \mathrm{L}$ for PCR amplication. Data of growth traits, including withers height, body length, height at hip cross, chest girth, abdominal girth, hip width, hucklebone width and shin circumferencec were recorded and used for subsequent analysis.

The tissue samples, such as heart, liver, spleen, lung, kidney, stomach, longissimus dorsi muscle, crureus and subcutaneous adipose tissue, with $2 \mathrm{~mm}$ cube in diameter, were collected from adult healthy female DBS cattle for spatial expression analysis. All tissue samples were harvested, immediately frozen in liquid nitrogen, and stored at $-80^{\circ} \mathrm{C}$ until analysis.

\section{Spatial expression of CFL2 mRNA in DBS cattle}

Quantitative real-time PCR was employed to detect spatial expression of CFL2 mRNA in DBS cattle. Total RNA were extracted from tissue samples using Trizol Reagent (Invitrogen, Carlsbad, CA, USA) and cDNA was prepared using the reverse transcription kit (Takara, Dalian, China) according to the manufacturer's procedures. Gene-specific primers (EXP-F: 5'-ATATGCTTTGTACGATGCCAC-3', EXP-R: 5'-AGCCATTTACTTGCCACTCAT-3') were designed for quantitative PCR, and GAPDH (F: 5'-AACCACGAGAAGTATAACAACACCC-3', R: 5'-TGGTCATAAGTCCCTCCACGAT-3') was amplified as an internal control. Each real-time PCR reaction was performed in a final volume of $20 \mu \mathrm{L}$ reaction mixture containing SYBR Premix Ex Taq (2×), Rox Reference Dye II (50×) (TaKaRa, Dalian, China), gene-specific primers, template cDNA and sterile water. The PCR amplification was performed on a 7500 Real-Time PCR System (Applied Biosystems, Foster City, CA, USA) under the following cycling conditions: $30 \mathrm{~s}$ at $95^{\circ} \mathrm{C}$, followed by 40 cycles at $95^{\circ} \mathrm{C}$ for $5 \mathrm{~s}, 60^{\circ} \mathrm{C}$ for $30 \mathrm{~s}$ and $72^{\circ} \mathrm{C}$ for $34 \mathrm{~s}$. RT-PCRs were performed in triplicate and the results were analyzed by the $2^{-\Delta \Delta C t}$ method (Livak et al., 2001).

\section{SNP detection}

Based on the sequence of the bovine CFL2 gene (GenBank accession number: NM_001076154.2), primer pairs were designed for SNP scanning and three SNP sites were identified by sequencing. A total of four cattle breed: Dabieshan cattle (DBS), Jiaxian red cattle (JX), Wannan cattle (WN) and Luxi cattle (LX), were involved to explore the SNP sites, and three SNPs g.1500G $>$ A (HinfI) in intron 2, g. 1694T $>\mathrm{A}($ Asel) in exon 4 and g. $2213 \mathrm{C}>\mathrm{G}($ HaeIII $)$ in 3'UTR were discovered.

The three SNPs were genotyped by (forced) PCRRFLP technique in 298 cattle in our experimental population. The PCR reactions were performed in a volume of $25 \mu \mathrm{L}$ containing $20 \mathrm{ng}$ DNA template, $12.5 \mathrm{uL}$ $2 *$ Taq Mix, $1.0 \mu \mathrm{L}$ each of primer $(100 \mathrm{ng} / \mu \mathrm{L})$ and sterile water. The PCR amplification comprised of the initial denaturation at $95{ }^{\circ} \mathrm{C}$ for $5 \mathrm{~min}, 32$ cycles of $30 \mathrm{sec}$ at $94{ }^{\circ} \mathrm{C}, 30 \mathrm{sec}$ at $\mathrm{Tm}$ specific for primer, and $30 \mathrm{sec}$ at $72^{\circ} \mathrm{C}$, followed by a final extension at $72^{\circ} \mathrm{C}$ for $5 \mathrm{~min}$. The RFLP reaction mixture consisted of $1 \mathrm{uL} 10^{*}$ buffer, $10 \mathrm{U}$ restriction enzyme (NEB, Ipswich, MA, USA), $5 \mathrm{uL}$ PCR products and sterile water. Samples were incubated at $37^{\circ} \mathrm{C}$ for restriction enzyme overnight. The digested products were analyzed by $3 \%$ agarose gel electrophoresis, stained with ethidium bromide, and visualized under UV illumination. The primers, fragment sizes and restriction enzymes selected were according to the study of Sun et al. (2015).

\section{Statistical analysis}

The allele and genotype frequencies were estimated by direct counting, Hardy-Weinberg equilibrium (HWE) was tested by POPGENE software (Version 3.2) based 
on the likelihood ratio for different locus-population combinations (Yeh et al., 1997). Population genetic indexes, including gene homozygosity (Ho), gene heterozygosity $(\mathrm{He}, \mathrm{Ho}+\mathrm{He}=1)$, effective allele numbers $(\mathrm{Ne})$ and polymorphism information content (PIC), were calculated according to Nei's methods (Nei et al., 1974; Botstein et al., 1980).

Linkage disequilibrium(LD) of the SNPs was analyzed by Haploview software according to the expectation maximization (EM) algorithm (Barrett et al., 2005). Haplotypes constructed was performed with the online SHEsis software (http://analysis2.bio-x.cn/myAnalysis. php) (Shi et al., 2005). The association between SNPs and growth traits in DBS cattle was analyzed using general linear models (GLM) with SAS software.

$$
\text { Yijk }=\mu+\mathrm{Bi}+\mathrm{Gj}+\varepsilon \mathrm{ijk} \text { (Wang et al., 2006) }
$$

Where Yijk is the phenotypic value of a target trait; $\mu$ represents the population mean, $\mathrm{Bi}$ is the combination effect, $\mathrm{Gj}$ is the genotype effect and eijk represents the random error.

\section{RESULTS}

\section{Sequence analysis of bovine CFL2 gene}

Sequence analysis revealed that bovine CFL2 cDNA (NM_001076154.2) comprised a 501-bp open reading frame (ORF) flanked by a 22-bp 5'UTR and 851-bp 3'UTR sequences. Bovine CFL2 gene shows 94\% and 86\% identity with human (NM_001243645.1) and mouse (NM_007688.2) counterparts, respectively. Further comparison revealed that each of the 5 -donor and 3 '-acceptor splice sites conformed to the GT-AG rule (Table I). Bovine CFL2 gene encodes a polypeptide of 166 amino acid residues with a calculated molecular mass of $18.7 \mathrm{kD}$ and an isolectric point of 8.1714 (http://weblab. cbi.pku.edu.cn/program.inputForm.do?program $=$ pepstats (v6.0.1)). The amino acid sequence shares $89 \%$ and 99\% sequence similarity with human (NP_001230574) and mouse (NP_031714.1) homologues, respectively. However, the bovine and mouse CFL2 has additional 17 amino acids more than human, respectively (shown in Fig. 1). Amino acid sequence analysis of bovine CFL2 revealed that the precursor protein contains actin depolymerisation factor (ADF), similar to the domains of the human (Q9Y281) CFL2 proteins.

\section{Spatial expression of CFL2 $m R N A$ in DBS cattle}

Quantitative real-time PCR analysis showed that bovine CFL2 mRNA expression varied greatly in diverse tissues, it is highly expressed in heart and stomach, moderately expressed in subcutaneous adipose tissue and crureus, and weakly expressed in other tissues.

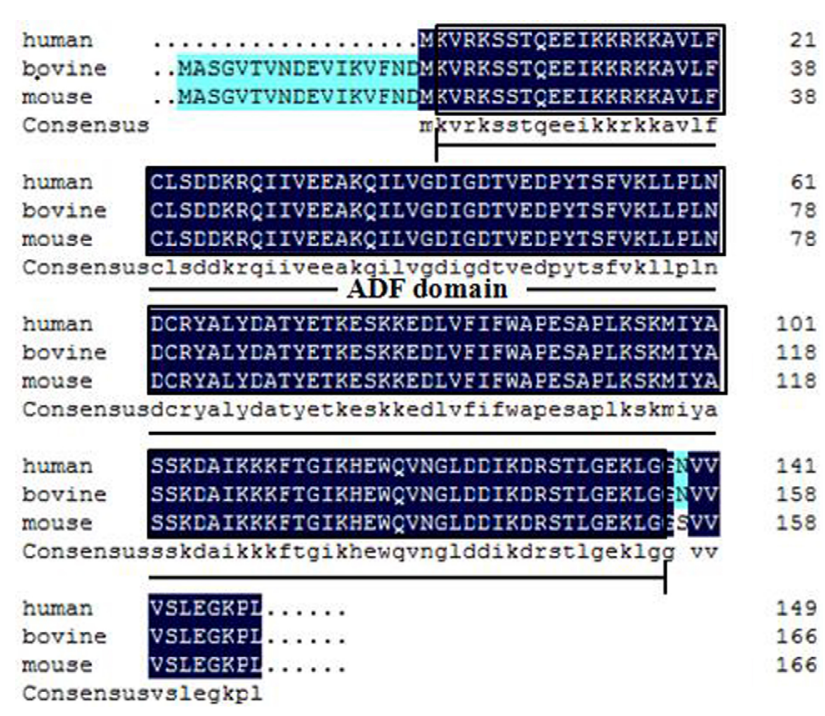

Fig. 1. Deduced amino acid sequence of bovine CFL2 compared with human CFL2 (NP_001230574) and mouse CFL2 (NP_001830.1). Shading shows identical amino acid residues among the three species. Common structural domains are indicated by boxes including ADF domain.

Table I. The exon/intron organizations of bovine $C F L 2$ gene.

\begin{tabular}{llllll}
\hline Gene & $\begin{array}{l}\text { Num- Exon } \\
\text { ber }\end{array}$ & $\begin{array}{l}\text { Intron } \\
\text { size(bp) }\end{array}$ & $\begin{array}{l}\text { 5' splice } \\
\text { size (bp) } \\
\text { donor }\end{array}$ & $\begin{array}{l}\text { 3' splice } \\
\text { acceptor }\end{array}$ \\
\hline CFL2 & 1 & 3 & 1076 & & ATGgtaagg \\
& 308 & 118 & ttcagGCTTC & TTCTGgtgtg \\
3 & 76 & 86 & tgtagGGCTC & TACAGgtaca \\
4 & 113 & & tttagGTAAT & \\
\hline
\end{tabular}

\section{SNP detection and genetic diversity analyses}

Three SNP sites were discovered through scanning DNA sequence of bovine CFL2 gene. The three SNPs, g. $1500 \mathrm{G}>\mathrm{A}$ in intron 2 with a HinfI site, g. 1694T $>$ A in exon 4 with a $V s p I$ site and g. $2213 \mathrm{C}>\mathrm{G}$ in 3'UTR with a HaeIII site were genotyped by (forced) PCR-RFLP technique in 298 cattle in our experimental population. After digestion by HinfI, the 389 bp PCR products were digested into $279 \mathrm{bp}$ and $110 \mathrm{bp}$ fragments (allele A) (Fig. 2A). At the g.1694T $>$ A locus, the 197 bp PCR amplicon can be digested by $V s p I$, producing $172 \mathrm{bp}$ and $25 \mathrm{bp}$ fragments for allele T (Fig. 2B). At the g. $2213 \mathrm{C}>\mathrm{G}$ locus, the 276 bp PCR fragment can be digested by HaeIII in fragment lengths of $252 \mathrm{bp}$ and $24 \mathrm{bp}$ for allele C (Fig. 2C). The $25 \mathrm{bp}$ and $24 \mathrm{bp}$ fragments were too small to stay in gel.

The genotype and allele frequencies are summarized in Table II. The results showed that the minor allele frequencies (MAF) ranged from 0.12-0.38. 
Table II. Allele frequency of $C F L 2$ gene in DBS cattle.

\begin{tabular}{|c|c|c|c|c|c|c|c|c|c|c|}
\hline \multirow[t]{2}{*}{ Loci } & \multirow{2}{*}{\multicolumn{3}{|c|}{$\begin{array}{l}\text { Genotypic } \\
\text { frequencies }\end{array}$}} & \multirow{2}{*}{\multicolumn{2}{|c|}{$\begin{array}{l}\text { Allelic frequen- } \\
\text { cies }\end{array}$}} & \multirow{2}{*}{$\begin{array}{l}\text { WE } \\
2\end{array}$} & \multicolumn{4}{|c|}{ Diversity parameter } \\
\hline & & & & & & & Ho & $\mathrm{He}$ & $\mathrm{Ne}$ & PIC \\
\hline \multirow[t]{2}{*}{ g. $1500 \mathrm{G}>\mathrm{A}$} & GG & GA & AA & G & A & & & & & \\
\hline & 0.16 & 0.45 & 0.39 & 0.38 & 0.62 & 0.27 & 0.528 & 0.472 & 1.893 & 0.361 \\
\hline \multirow[t]{2}{*}{ g. $1694 \mathrm{~T}>\mathrm{A}$} & $\mathrm{TT}$ & TA & $\mathrm{AA}$ & $\mathrm{T}$ & A & & & & & \\
\hline & 0.06 & 0.46 & 0.48 & 0.29 & 0.71 & 3.46 & 0.588 & 0.412 & 1.701 & 0.327 \\
\hline \multirow[t]{2}{*}{ g. $2213 \mathrm{C}>\mathrm{G}$} & $\mathrm{CC}$ & $\mathrm{CG}$ & GG & $\mathrm{C}$ & G & & & & & \\
\hline & 0.01 & 0.22 & 0.77 & 0.12 & 0.88 & 1.56 & 0.793 & 0.207 & 1.261 & 0.186 \\
\hline
\end{tabular}

Table III. Association analysis of CFL2 gene different genotypes with growth traits in Dabieshan cattle.

\begin{tabular}{|c|c|c|c|c|c|c|c|c|}
\hline genotypes & $\begin{array}{l}\text { body length } \\
(\mathrm{cm})\end{array}$ & $\begin{array}{l}\text { withers height } \\
\text { (cm) }\end{array}$ & $\begin{array}{l}\text { height at hip } \\
\operatorname{cross}(\mathrm{cm})\end{array}$ & $\begin{array}{l}\text { chest girth } \\
(\mathrm{cm})\end{array}$ & $\begin{array}{l}\text { abdominal } \\
\text { girth }(\mathrm{cm})\end{array}$ & $\begin{array}{l}\text { shin circum- } \\
\text { ference }(\mathrm{cm})\end{array}$ & $\begin{array}{l}\text { hip width } \\
\text { (cm) }\end{array}$ & $\begin{array}{l}\text { hucklebone } \\
\text { width }(\mathrm{cm})\end{array}$ \\
\hline \multicolumn{9}{|l|}{ g. $1500 \mathrm{G}>\mathrm{A}$} \\
\hline AA & $126.04 \pm 0.90$ & $110.21 \pm 0.54 \mathrm{a}$ & $109.50 \pm 0.57$ & $147.99 \pm 1.47$ & $169.37 \pm 1.47$ & $16.79 \pm 0.14$ & $31.66 \pm 0.44$ & $17.41 \pm 0.16$ \\
\hline $\mathrm{AG}$ & $125.55 \pm 0.81$ & $109.89 \pm 0.55 \mathrm{a}$ & $109.89 \pm 0.43$ & $148.98 \pm 0.89$ & $170,19 \pm 1.27$ & $16.94 \pm 0.16$ & $32.11 \pm 0.37$ & $17.40 \pm 0.24$ \\
\hline GG & $125.76 \pm 1.73$ & $107.46 \pm 1.10 \mathrm{~b}$ & $109.36 \pm 0.94$ & $148.49 \pm 1.82$ & $168.00 \pm 2.37$ & $16.52 \pm 0.25$ & $31.12 \pm 0.78$ & $16.85 \pm 0.41$ \\
\hline$P$-value & 0.925 & 0.040 & 0.805 & 0.838 & 0.701 & 0.361 & 0.415 & 0.429 \\
\hline \multicolumn{9}{|l|}{ g. $1694 \mathrm{~T}>\mathrm{A}$} \\
\hline $\mathrm{TT}$ & $124.83 \pm 3.06$ & $107.39 \pm 2.07$ & $109.50 \pm 1.53$ & $146.89 \pm 3.98 \mathrm{a}$ & $169.33 \pm 4.21$ & $16.44 \pm 0.42$ & $30.02 \pm 1.22$ & $17.00 \pm 0.66$ \\
\hline $\mathrm{TA}$ & $126.01 \pm 0.82$ & $109.83 \pm 0.56$ & $109.72 \pm 0.46$ & $149.70 \pm 0.89 b$ & $169.80 \pm 1.26$ & $16.93 \pm 0.15$ & $32.11 \pm 0.37$ & $17.15 \pm 0.24$ \\
\hline AA & $125.68 \pm 0.81$ & $109.75 \pm 0.50$ & $109.60 \pm 0.49$ & $146.29 \pm 1.24 \mathrm{a}$ & $169.29 \pm 1.32$ & $16.76 \pm 0.14$ & $32.04 \pm 0.40$ & $17.52 \pm 0.23$ \\
\hline$P$-value & 0.880 & 0.299 & 0.976 & 0.048 & 0.960 & 0.441 & 0.053 & 0.475 \\
\hline \multicolumn{9}{|l|}{ g. $2213 \mathrm{C}>\mathrm{G}$} \\
\hline $\mathrm{CC}$ & $126.00 \pm 0.60$ & $109.00 \pm 0.91$ & $111.50 \pm 0.35$ & $140.00 \pm 0.40 \mathrm{a}$ & $161.00 \pm 1.19 \mathrm{a}$ & $17.00 \pm 0.05$ & $27.50 \pm 0.55 \mathrm{a}$ & $17.00 \pm 0.20$ \\
\hline $\mathrm{CG}$ & $124.51 \pm 1.17$ & $110.58 \pm 0.79$ & $109.96 \pm 0.72$ & $148.03 \pm 1.21 \mathrm{~b}$ & $167.36 \pm 1.48 b$ & $17.00 \pm 0.20$ & $31.64 \pm 0.50 \mathrm{~b}$ & $17.22 \pm 0.32$ \\
\hline GG & $125.85 \pm 0.64$ & $109.14 \pm 0.41$ & $109.34 \pm 0.35$ & $146.69 \pm 0.88 b$ & $170.24 \pm 1.01 b$ & $16.71 \pm 0.10$ & $31.69 \pm 0.31 b$ & $17.20 \pm 0.15$ \\
\hline$P$-value & 0.573 & 0.253 & 0.606 & 0.036 & 0.042 & 0.272 & 0.046 & 0.992 \\
\hline
\end{tabular}

Note: 1 ). The values is marked with mean $\pm \mathrm{SE} ; 2$ ). Values with different superscripts within the same row differ significantly at $\mathrm{p}<0.05$ (a, $\mathrm{b})$.

SNP g.2213C $>\mathrm{G}$ was almost completely monomorphic $(\mathrm{MAF}=0.01)$ in our population and other two SNPs were polymorphic. A chi-square test showed that the genotypic distributions within all individuals were in agreement with the Hardy-Weinberg equilibrium $(\mathrm{p}>0.05)$. Genetic indices, including $\mathrm{Ho}, \mathrm{He}, \mathrm{Ne}$ and $\mathrm{PIC}$, were measured to detect the informativeness of the identified SNPs. PIC values ranged from 0.186 to 0.361 , and SNP g.1500G $>$ A revealed the highest PIC value (0.361), which corresponds to the highest $\mathrm{He}(0.472)$.

Linkage disequilibrium, haplotypes and association analysis

The linkage disequilibrium was evaluated for all pairs of SNPs using $r^{2}$, and the values of $r^{2}>0.33$ might indicate a sufficiently strong linkage disequilibrium (LD) to be useful for mapping (Ardlie et al., 2002). The LD between the three SNPs in the population indicated that the $\mathrm{D}^{\prime}$ values ranged from 0.886 to 0.938 , and the $\mathrm{r}^{2}$ values ranged from 0.170 to 0.653 . SNP g. $1500 \mathrm{G}>\mathrm{A}$ and g. $1694 \mathrm{~T}>\mathrm{A}$ had $\mathrm{a}$ strong LD and there was a low LD between the rests of any two sites (Table IV).

Haplotypes in 298 individuals were analyzed using the online SHEsis software, and four major haplotypes accounting for $99.1 \%$ of the alleles were observed (Table $\mathrm{V})$, excepting for 3 haplotypes with a frequency of $<0.03$. The haplotype 'AAG' was the most common haplotype and has a great frequency of $61.2 \%$, next coming the haplotype GTG, GAG and GTC were quite rare, at a frequency of 0.090 and 0.101 , respectively. 


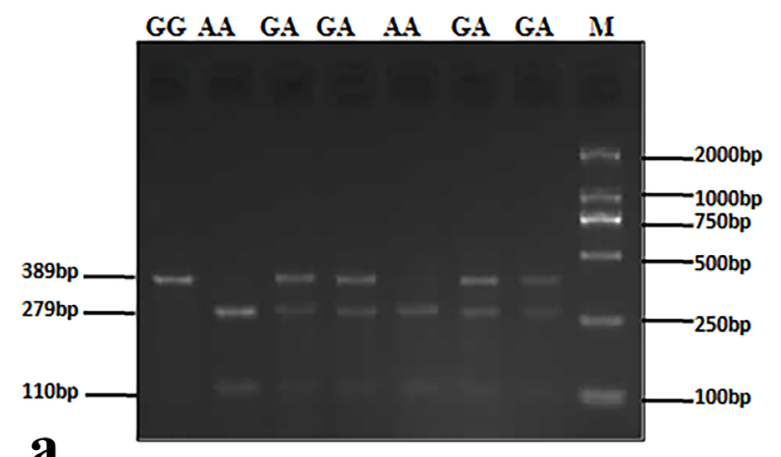

a
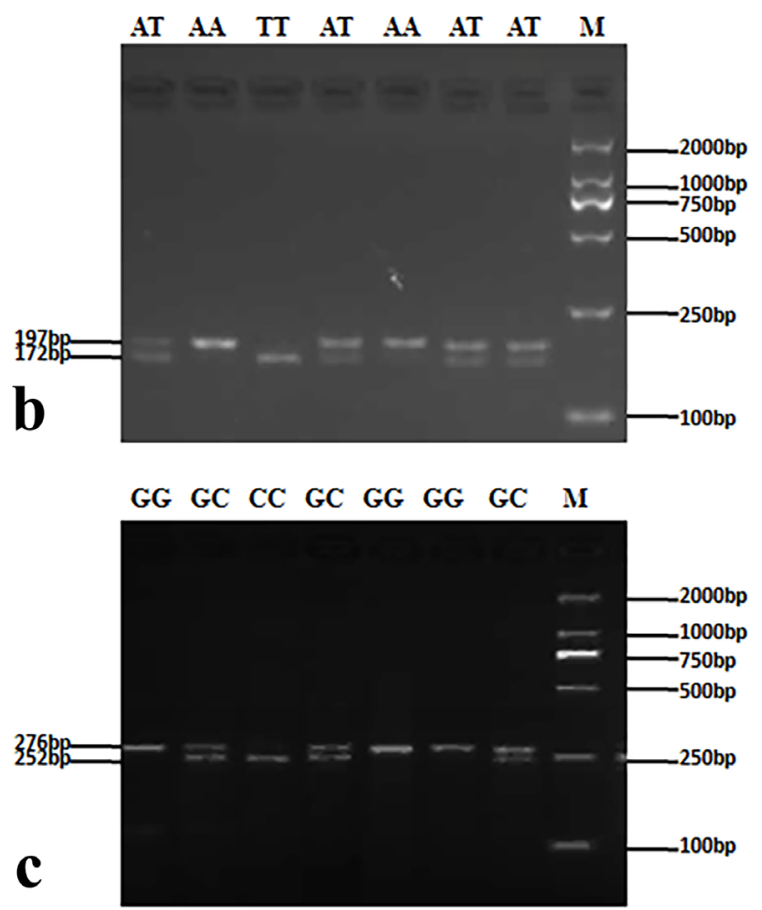

Fig. 2. Electrophoretic patterns of SNP genotyping by PCR-RFLP method; (a) is the PCR-HinfI-RFLP analysis result of SNP at g.1500G $>$ A in intron 2 of the CFL2 gene, genotype GA $(389+279+110 \mathrm{bp})$, genotype AA $(279+$ $110 \mathrm{bp}$ ) and genotype GG (389 bp); (b) is the PCR-VspIRFLP analysis result of SNP at g.1694T $>$ A in exon 4 of the CFL2 gene, genotype AT $(197+172+25 \mathrm{bp}, 25 \mathrm{bp}$ fragment was too small to stay in gel), genotype TT (172 $+25 \mathrm{bp}$ ) and genotype AA (197 bp); (c) is the PCR- HaeIII-RFLP analysis result of SNP at g.2213C $>$ G in 3'UTR of the CFL2 gene, genotype CG $(276+252+24 \mathrm{bp} ; 24 \mathrm{bp}$ fragment was too small to stay in gel), genotype CC (252 $+24 \mathrm{bp}$ ) and genotype GG (276 bp); M refers to the DNA molecular weight marker.

The associations between CFL2 genotypes and growth traits were analyzed in our population. As shown in Table III, SNP g.1500G $>$ A was associated with withers height $(\mathrm{p}=0.040)$, SNP g.1694T $>$ A was associated with chest girth $(\mathrm{p}=0.048)$, and $\mathrm{g} .2213 \mathrm{C}>\mathrm{G}$ site has a significant association with chest girth $(\mathrm{p}=0.036)$, abdominal girth $(\mathrm{p}=0.042)$ and hip width $(\mathrm{p}=0.046)$. Furthermore, based on the haplotypes analysis, nine combined genotypes were found in the animal DNA samples of this study. However, the associated analysis suggested that no significant differences were detected between the combined genotypes of the three SNPs and eight growth traits in DBS cattle ( $>>0.05$ ) (Table VI).

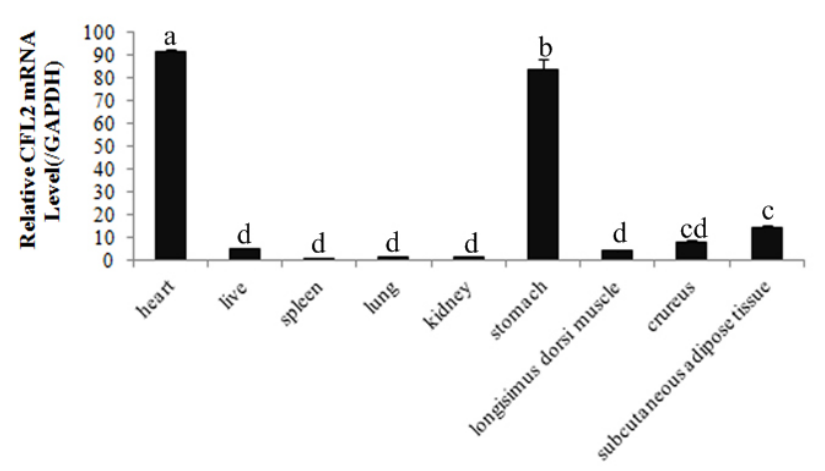

Fig. 3. Expression pattern analysis of CFL2 mRNA in DBS cattle by real-time PCR method. The value of CLF2 in spleen was arbitrarily set to 1.0. The different letters ( $a, b, c$ and d) indicate a p-value of less than 0.05 in a Student's t-test.

Table IV. The estimated values of linkage disequilibrium analysis between three mutation sites within the bovine CFL2 gene.

\begin{tabular}{llll}
\hline Loci & g.1500G $>$ A & g.1694T $>$ A & g.2213C $>$ G \\
\hline g.1500G $>A$ & & $D^{\prime}=0.938$ & $D^{\prime}=0.924$ \\
g.1694T $>A$ & $r^{2}=0.653$ & & $D^{\prime}=0.886$ \\
g. $2213 C>G$ & $r^{2}=0.170$ & $r^{2}=0.239$ & \\
\hline
\end{tabular}

Table V. Haplotypes of the CFL2 gene and their frequencies in the DBS cattle breed.

\begin{tabular}{|c|c|c|c|c|}
\hline Haplotype & g.1500G $>A$ & g.1694T $>A$ & g.2213C $>G$ & Frequency \\
\hline 1 & A & A & G & 0.612 \\
\hline 2 & G & A & G & 0.090 \\
\hline 3 & G & $\mathrm{T}$ & $\mathrm{C}$ & 0.101 \\
\hline 4 & $\mathrm{G}$ & $\mathrm{T}$ & $\mathrm{G}$ & 0.188 \\
\hline
\end{tabular}

Note: frequency $>0.03$ has been ignored in the analysis. 
Table VI. Associations of combined genotypes with growth traits in Dabieshan cattle (mean $\pm \mathrm{SE}$ ).

\begin{tabular}{|c|c|c|c|c|c|c|c|c|c|}
\hline $\begin{array}{l}\text { Genotype } \\
\text { of combi- } \\
\text { nation } \\
\end{array}$ & $\begin{array}{l}\text { Number } \\
\text { of com- } \\
\text { binations }\end{array}$ & $\begin{array}{l}\text { Body length } \\
(\mathrm{cm})\end{array}$ & $\begin{array}{l}\text { Body height } \\
\text { (cm) }\end{array}$ & $\begin{array}{l}\text { Height at hip } \\
\text { cross }(\mathrm{cm})\end{array}$ & $\begin{array}{l}\text { Chest girth } \\
\text { (cm) }\end{array}$ & $\begin{array}{l}\text { abdominal } \\
\text { girth }(\mathrm{cm})\end{array}$ & $\begin{array}{l}\text { shank cir- } \\
\text { cumference } \\
\text { (cm) }\end{array}$ & $\begin{array}{l}\text { Hucklebone } \\
\text { width }(\mathrm{cm})\end{array}$ & $\begin{array}{l}\text { Hip width } \\
\text { (cm) }\end{array}$ \\
\hline AAAAGG & 112 & $125.93 \pm 0.98$ & $110.12 \pm 0.58$ & $109.54 \pm 0.55$ & $148.04 \pm 1.59$ & $169.41 \pm 1.59$ & $16.79 \pm 1.56$ & $31.60 \pm 2.19$ & $17.48 \pm 0.43$ \\
\hline AGATGG & 63 & $126.62 \pm 0.88$ & $109.33 \pm 0.65$ & $109.60 \pm 1.43$ & $150.91 \pm 0.99$ & $172.60 \pm 1.52$ & $16.81 \pm 0.80$ & $32.62 \pm 0.63$ & $17.29 \pm 0.32$ \\
\hline AGAAGG & 21 & $123.24 \pm 0.96$ & $108.33 \pm 0.59$ & $110.34 \pm 0.45$ & $149.91 \pm 0.86$ & $169.65 \pm 1.43$ & $16.90 \pm 0.87$ & $31.38 \pm 1.34$ & $18.00 \pm 0.56$ \\
\hline AGATGC & 47 & $125.15 \pm 0.95$ & $111.32 \pm 0.60$ & $110.09 \pm 1.52$ & $145.98 \pm 1.08$ & $167.19 \pm 1.30$ & $17.13 \pm 0.69$ & $31.74 \pm 0.71$ & $17.29 \pm 1.59$ \\
\hline GGATGG & 16 & $126.63 \pm 1.25$ & $106.93 \pm 0.58$ & $108.31 \pm 0.79$ & $148.75 \pm 1.88$ & $167.69 \pm 1.64$ & $16.75 \pm 1.57$ & $30.69 \pm 1.83$ & $15.85 \pm 0.47$ \\
\hline GGATGC & 7 & $124.86 \pm 0.89$ & $111.00 \pm 0.83$ & $111.28 \pm 1.89$ & $147.00 \pm 1.26$ & $167.00 \pm 1.06$ & $17.17 \pm 1.32$ & $31.00 \pm 0.51$ & $17.86 \pm 0.85$ \\
\hline GGAAGG & 4 & $129.25+0.78$ & $107.75 \pm 0.53$ & $108.67 \pm 1.72$ & $149.50 \pm 1.30$ & $165.50 \pm 1.77$ & $15.50 \pm 1.00$ & $34.33 \pm 1.08$ & $17.67 \pm 0.52$ \\
\hline GGTTGG & 10 & $125.10 \pm 1.03$ & $106.20 \pm 1.99$ & $108.30 \pm 1.32$ & $148.30 \pm 2.16$ & $171.30 \pm 0.69$ & $16.10 \pm 0.52$ & $29.90 \pm 1.19$ & $16.50 \pm 0.88$ \\
\hline GGTTGC & 7 & $123.14 \pm 1.12$ & $109.00 \pm 0.59$ & $110.58 \pm 0.67$ & $149.57 \pm 1.09$ & $165.00 \pm 0.90$ & $16.86 \pm 1.26$ & $31.00 \pm 0.51$ & $17.67 \pm 0.80$ \\
\hline P-value & & 0.598 & 0.303 & 0.118 & 0.389 & 0.564 & 0.591 & 0.206 & 0.864 \\
\hline
\end{tabular}

Note: Number $>3$ has been ignored in the analysis.

\section{DISCUSSION}

The results of our study provide the comparison of CFL2 genome structure with that human and mouse, demonstrated remarkably high similarity among the three species; they all contained four exons and three introns. The ADF (Actin depolymerisation factor) domain, may be severing actin filaments and binding to actin monomers, is highly conserved among human, mouse and cattle. Comparing our results with human CFL2 microarray expression data (http://genome.ucsc.edu/), the expression pattern of bovine CFL2 gene was partial coincided with the expression of the corresponding gene in human, which it was expressed at considerable levels in heart, and this could be linked to their tissue-specific function. Furthermore, the expression analysis indicated that CFL2 gene was actively transcribed in heart and stomach, subcutaneous adipose tissue, crureus, longissimus dorsi muscle and live tissues, which were rich in muscle fiber, indicated that CFL2 gene play a vital role in muscle tissues, and may further affect the phenotype of domesticated animal.

CFL2 gene was reported involving in the muscle development and play a critical role in muscle maintenance (Gurniak et al., 2014). CFL2 mutations may affect F-actin accumulation and trigger congenital myopathy with protein aggregates and nemaline bodies in human (Fagerberg et al., 2014; Yue et al., 2014). In chicken and Chinese QC cattle, SNPs of CFL2 gene were associated with the growth traits and may affect the phenotypes of the individuals. Our study documented three SNPs of CFL2 gene were associated with growth traits of DBS cattle. SNP g.1500G $>$ A was associated with withers height, and the cattle with genotypes AA and AG had significantly greater withers height than those with genotypes HinfIGG $(\mathrm{p}<0.05)$, demonstrating that the allele HinfI-A might be correlated with an increase in withers height in the DBS population. SNP g. $2213 \mathrm{C}>\mathrm{G}$ site has a significant association with chest girth, abdominal girth and hip width, and the animals with genotypes GG and CG had significantly greater chest girth, abdominal girth and hip width than those with genotypes $\mathrm{CC}(\mathrm{p}<0.05)$, indicating that the allele HaeIII-G might be correlated with an increase in chest girth, abdominal girth and hip width in the DBS population. The SNPs g. $1500 \mathrm{G}>\mathrm{A}$ in intron 2 and g.2213C $>$ G in 3' UTR may exert specific biological functions of genes by influencing transcriptional efficiency (Greenwood et al., 2003; Le Hir et al., 2003). In exon 4, SNP g.1694T $>$ A has a significant association with chest girth, the animals with genotypes TA had significantly greater chest girth than those with genotypes TT and AA $(\mathrm{P}<0.05)$. Moreover, SNP g. 1694T $>$ A was a synonymous mutation (Ile $131 \mathrm{Ile}$ ), and may alter the function of proteins and change cellular response to specific targets by affecting messenger RNA splicing, stability and protein structure (Hunt et al., 2009).

Haplotypes, which can be regarded as a collection of ordered markers, are specifically physical arrangements of SNP alleles on the same chromosome (Olivier et al., 2003). In general, because of the higher heterozygosity and multiallelic nature, haplotypes may provide greater power than individual marker analysis for genetic disease and trait associations (Akey et al., 2001). With the integration of haplotypes, the molecular markers could be accurately identified and the single SNP could be precisely 
associated with character information (Scheike et al., 2010). Especially when the marker alleles are not in strong LD with each other, the haplotypes analysis has a greatest power advantage (Morris et al., 2002). Unfortunately, the association analysis of combined genotypes of CFL2 gene among our detected individuals indicated no convincing associations with any of the studied traits; this may be due to the limited population, and more samples and more traits should be considered in the future.

\section{CONCLUSIONS}

In conclusion, three polymorphisms of CFL2 gene in DBS cattle were observed in this study. We have also defined the LD and haplotypes in the DBS cattle and identified the preponderant haplotype AAG, which would provide a background for more extensive characterization of the bovine CFL2 gene. Although the combined genotypes of CFL2 gene have no convincing associations with the studied traits, association analyses indicated that its polymorphisms were associated with growth traits of DBS cattle. In addition, the spatial expression indicated that $C F L 2$ gene was varied expression in adult DBS cattle tissues. Our study suggests $C F L 2$ gene may affect the phenotype of domesticated animal, and its polymorphisms might be used as a genetic marker and for the breeding of new beef cattle.

\section{ACKNOWLEDGMENTS}

This study was supported by the Youth Innovation Fund of Anhui Academy of Agricultural Sciences (17B0408), the Innovative Construction Project of Anhui Province (18030701207), the Program of National Beef Cattle Yak Industrial Technology System (CARS-37), the Anhui Province Key Laboratory of Livestock and Poultry Product Safety Engineering, and the Open Fund of Anhui Province Key Laboratory of Local Livestock and Poultry, Genetical Resource Conservation and Breeding (AKLGRCB2017010).

\section{Statement of conflict of interest}

The authors declare that they have no conflict of interest.

\section{REFERENCES}

Abe, H., Endo, T., Yamamoto, K. and Obinatam, T., 1990. Sequence of cDNAs encoding actin depolymerizing factor and cofilin of embryonic chicken skeletal muscle: two functionally distinct actin-regulatory proteins exhibit high structural homology. Biochemistry, 29: 7420-7425. https:// doi.org/10.1021/bi00484a010

Agrawal, P.B., Greenleaf, R.S., Tomczak, K.K., Lehtokari, V.L., Wallgren-Pettersson, C., Wallefeld, W., Laing, N.G., Darras, B.T., Maciver, S.K., Dormitzer, P.R. and Beggs, A.H., 2007. Nemaline myopathy with minicores caused by mutation of the CFL2 gene encoding the skeletal muscle actinbinding protein, cofilin-2. Am. J. Hum. Genet., 80: 162-167. https://doi.org/10.1086/510402

Akey, J., Jin, L. and Xiong, M., 2001. Haplotypes vs single marker linkage disequilibrium tests: what do we gain? Eur. J. Hum. Genet., 9: 291-300. https:// doi.org/10.1038/sj.ejhg.5200619

Ardlie, K.G., Kruglyak, L. and Seielstad, M., 2002. Patterns of linkage disequilibrium in the human genome. Nat. Rev. Genet., 3: 299-309. https://doi. org $/ 10.1038 / \mathrm{nrg} 777$

Bamburg, J.R., 1999. Proteins of the ADF/cofilin family: essential regulators of actin dynamics. Annu. Rev. Cell Dev. Biol., 15: 185-230. https://doi. org/10.1146/annurev.cellbio.15.1.185

Barrett, J.C., Fry, B., Maller, J. and Daly, M.J., 2005. Haploview: analysis and visualization of LD and haplotype maps. Bioinformatics, 21: 263-265. https://doi.org/10.1093/bioinformatics/bth457

Bian, Y., Guo, J., Qiao, L. and Sun, X., 2018. miR3189-3p Mimics enhance the effects of S100A4 siRNA on the inhibition of proliferation and migration of gastric cancer cells by targeting CFL2. Int. J. mol. Sci., 19: E236. https://doi.org/10.3390/ ijms19010236

Botstein, D., White, R.L., Skolnick, M. and Davis, R.W., 1980. Construction of a genetic linkage map in man using restriction fragment length polymorphisms. Am. J. Hum. Genet., 32: 314-331.

Czosnek, H., Nudel, U., Shani, M., Barker, P.E., Pravtcheva, D.D., Ruddle, F.H. and Yaffe, D., 1982. The genes coding for the muscle contractile proteins, myosin heavy chain, myosin light chain 2 , and skeletal muscle actin are located on three different mouse chromosomes. EMBO J., 1: 12991305. https://doi.org/10.1002/j.1460-2075.1982. tb01314.x

Fagerberg, L., Hallstrom, B.M., Oksvold, P., Kampf, C., Djureinovic, D., Odeberg, J., Habuka, M., Tahmasebpoor, S., Danielsson, A., Edlund, K., Asplund, A., Sjostedt, E., Lundberg, E., Szigyarto, C.A., Skogs, M., Takanen, J.O., Berling, H., Tegel, H., Mulder, J., Nilsson, P., Schwenk, J.M., Lindskog, C., Danielsson, F., Mardinoglu, A., Sivertsson, A., von Feilitzen, K., Forsberg, M., 
Zwahlen, M., Olsson, I., Navani, S., Huss, M., Nielsen, J., Ponten, F. and Uhlen, M., 2014. Analysis of the human tissue-specific expression by genomewide integration of transcriptomics and antibodybased proteomics. Mol. Cell Proteom., 13: 397-406. https://doi.org/10.1074/mcp.M113.035600

Fattori, F., Fiorillo, C., Rodolico, C., Tasca, G., Verardo, M., Bellacchio, E., Pizzi, S., Ciolfi, A., Fagiolari, G., Lupica, A., Broda, P., Pedemonte, M., Moggio, M., Bruno, C., Tartaglia, M., Bertini, E. and D’Amico, A., 2018. Expanding the histopathological spectrum of CFL2-related myopathies. Clin. Genet., 93: 12341239. https://doi.org/10.1111/cge.13240

Greenwood, T.A. and Kelsoe, J.R., 2003. Promoter and intronic variants affect the transcriptional regulation of the human dopamine transporter gene. Genomics, 82: $\quad 511-520 . \quad$ https://doi.org/10.1016/S08887543(03)00142-3

Gurniak, C.B., Chevessier, F., Jokwitz, M., Jonsson, F., Perlas, E., Richter, H., Matern, G., Boyl, P.P., Chaponnier, C., Furst, D., Schroder, R. and Witke, W., 2014. Severe protein aggregate myopathy in a knockout mouse model points to an essential role of cofilin2 in sarcomeric actin exchange and muscle maintenance. Eur. J. Cell Biol., 93: 252-266. https:// doi.org/10.1016/j.ejcb.2014.01.007

Hunt, R., Sauna, Z.E., Ambudkar, S.V., Gottesman, M.M. and Kimchi-Sarfaty, C., 2009. Silent (synonymous) SNPs: should we care about them? Meth. mol. Biol., 578: 23-39. https://doi.org/10.1007/978-1-60327411-1_2

Le Hir, H., Nott, A. and Moore, M.J., 2003. How introns influence and enhance eukaryotic gene expression. Trends Biochem. Sci., 28: 215-220. https://doi. org/10.1016/S0968-0004(03)00052-5

Kremneva, E., Makkonen, M.H., SkwarekMaruszewska, A., Gateva, G., Michelot, A., Dominguez, R., Lappalainen, P., 2014. Cofilin-2 controls actin filament length in muscle sarcomeres. Dev. Cell, 31: 215-226. https://doi.org/10.1016/j. devcel.2014.09.002

Livak, K.J. and Schmittgen, T.D., 2001. Analysis of relative gene expression data using realtime quantitative PCR and the 2(-Delta Delta C (T)) method. Methods, 25: 402-428. https://doi. org/10.1006/meth.2001.1262

Maciver, S.K. and Hussey, P.J., 2002. The ADF/cofilin family: actin-remodeling proteins. Genome Biol., 3: reviews 3007.

McKim, K.S., Matheson, C., Marra, M.A., Wakarchuk, M.F. and Baillie, D.L., 1994. The Caenorhabditis elegans unc-60 gene encodes proteins homologous to a family of actin-binding proteins. Mol. Gen. Genet., 242: 346-357. https://doi.org/10.1007/ BF00280425

Mohri, K., Takano-Ohmuro, H., Nakashima, H., Hayakawa, K., Endo, T., Hanaoka, K. and Obinata, T., 2000. Expression of cofilin isoforms during development of mouse striated muscles. J. Muscle Res. Cell Motil., 21: 49-57. https://doi. org/10.1023/A:1005682322132

Morris, R.W. and Kaplan, N.L., 2002. On the advantage of haplotype analysis in the presence of multiple disease susceptibility alleles. Genet. Epidemiol., 23: 221-233. https://doi.org/10.1002/gepi.10200

Nei, M. and Roychoudhury, A.K., 1974. Sampling variances of heterozygosity and genetic distance. Genetics, 76: 379-390.

Nishida, E., Maekawa, S. and Sakai, H., 1984. Cofilin, a protein in porcine brain that binds to actin filaments and inhibits their interactions with myosin and tropomyosin. Biochemistry, 23: 5307-5313. https:// doi.org/10.1021/bi00317a032

Shi, Y.Y. and He, L., 2005. SHEsis, a powerful software platform for analyses of linkage disequilibrium, haplotype construction, and genetic association at polymorphism loci. Cell Res., 15: 97-98. https://doi. org/10.1038/sj.cr.7290272

Olivier, M., 2003. A haplotype map of the human genome. Physiol. Genom., 13: 3-9. https://doi.org/10.1152/ physiolgenomics.00178.2002

Ong, R.W., AlSaman, A., Selcen, D., Arabshahi, A., Yau, K.S., Ravenscroft, G., Duff, R.M., Atkinson, V., Allcock, R.J. and Laing, N.G., 2014. Novel cofilin-2 (CFL2) four base pair deletion causing nemaline myopathy. J. Neurol. Neurosurg. Psychia., 85: 10581060. https://doi.org/10.1136/jnnp-2014-307608

Ono, S., Minami, N., Abe, H. and Obinata, T., 1994. Characterization of a novel cofilin isoform that is predominantly expressed in mammalian skeletal muscle. J. biol. Chem., 269: 15280-15286.

Rangrez, A.Y., Hoppe, P., Kuhn, C., Zille, E., Frank, J., Frey, N. and Frank, D., 2017. MicroRNA miR301 a is a novel cardiac regulator of Cofilin-2. PLoS One, 12: e0183901. https://doi.org/10.1371/journal. pone. 0183901

Scheike, T.H., Martinussen, T., Silver, J.D., 2010. Estimating haplotype effects for survival data. Biometrics, 66: 705-715. https://doi.org/10.1111/ j.1541-0420.2009.01329.X

Sun, Y., Lan, X., Lei, C., Zhang, C. and Chen, H., 2015. Haplotype combination of the bovine CFL2 gene sequence variants and association with growth traits in Qinchuan cattle. Gene, 563: 136-141. https://doi. 
org/10.1016/j.gene.2015.03.016

Vartiainen, M.K., Mustonen, T., Mattila, P.K., Ojala, P.J., Thesleff, I., Partanen, J., Lappalainen, P., 2002. The three mouse actin-depolymerizing factor/cofilins evolved to fulfill cell-type-specific requirements for actin dynamics. Mol. Biol. Cell, 13: 183-194. https:// doi.org/10.1091/mbc.01-07-0331

Wang, H.L., Wang, H., Zhu, Z.M., Wang, C.F., Zhu, M.J., Mo de, L., Yang, S.L. and Li, K., 2006. Subcellular localization, expression patterns, SNPs and association analyses of the porcine HUMMLC2B gene. Mol. Genet. Genom., 276: 264-272. https:// doi.org/10.1007/s00438-006-0142-8

Yeh, F.C., Yang, R., Boyle, T.B.J., Ye, Z. and Mao, J.X., 1997. POPGENE, the user-friendly shareware for population genetic analysis. Molecular Biology and Biotechnology Centre, University of Alberta, Canada.

Yue, F., Cheng, Y., Breschi, A., Vierstra, J., Wu, W., Ryba, T., Sandstrom, R., Ma, Z., Davis, C., Pope, B.D., Shen, Y., Pervouchine, D.D., Djebali, S., Thurman, R.E., Kaul, R., Rynes, E., Kirilusha, A., Marinov, G. K., Williams, B.A., Trout, D., Amrhein, H., FisherAylor, K., Antoshechkin, I., DeSalvo, G., See, L.H., Fastuca, M., Drenkow, J., Zaleski, C., Dobin, A., Prieto, P., Lagarde, J., Bussotti, G., Tanzer, A., Denas, O., Li, K., Bender, M.A., Zhang, M., Byron, R., Groudine, M.T., McCleary, D., Pham, L., Ye, Z., Kuan, S., Edsall, L., Wu, Y.C., Rasmussen, M.D., Bansal, M.S., Kellis, M., Keller, C.A., Morrissey,
C.S., Mishra, T., Jain, D., Dogan, N., Harris, R.S., Cayting, P., Kawli, T., Boyle, A.P., Euskirchen, G., Kundaje, A., Lin, S., Lin, Y., Jansen, C., Malladi, V.S., Cline, M.S., Erickson, D.T., Kirkup, V.M., Learned, K., Sloan, C.A., Rosenbloom, K.R., Lacerda de Sousa, B., Beal, K., Pignatelli, M., Flicek, P., Lian, J., Kahveci, T., Lee, D., Kent, W.J., Ramalho Santos, M., Herrero, J., Notredame, C., Johnson, A., Vong, S., Lee, K., Bates, D., Neri, F., Diegel, M., Canfield, T., Sabo, P.J., Wilken, M.S., Reh, T.A., Giste, E., Shafer, A., Kutyavin, T., Haugen, E., Dunn, D., Reynolds, A.P., Neph, S., Humbert, R., Hansen, R.S., De Bruijn, M., Selleri, L., Rudensky, A., Josefowicz, S., Samstein, R., Eichler, E.E., Orkin, S.H., Levasseur, D., Papayannopoulou, T., Chang. K.H., Skoultchi. A., Gosh, S., Disteche, C., Treuting, P., Wang, Y., Weiss, M.J., Blobel, G.A., Cao, X., Zhong, S., Wang, T., Good, P.J., Lowdon, R. F., Adams, L.B., Zhou, X.Q., Pazin, M.J., Feingold, E.A., Wold, B., Taylor, J., Mortazavi, A., Weissman, S.M., Stamatoyannopoulos, J.A., Snyder, M.P., Guigo, R., Gingeras, T.R., Gilbert, D.M., Hardison, R. C., Beer, M.A., Ren, B. and Mouse, E.C., 2014. A comparative encyclopedia of DNA elements in the mouse genome. Nature, 515: 355-364. https://doi. org/10.1038/nature 13992

Zhao, Q., 2011. Study on genetic variation and its effects and expression of CFL2 gene in chickens. Master thesis, Henan Agricultural University. Zhengzhou, China. 